\title{
PENGARUH PERCEIVED ORGANIZATIONAL SUPPORT (POS) TERHADAP KOMITMEN ORGANISASI SMA NEGERI DI KOTA PALANGKA RAYA
}

\author{
Christian Radiafilsan \\ FKIP, Universitas Palangka Raya \\ E-mail: chrisitan.rf@fkip.upr.ac.id
}

\begin{abstract}
Abstrak: Tujuan dari penelitian ini adalah untuk mengetahui secara komprehensif pengaruh dari Perceived Organizational Support (POS) terhadap Komitmen Organisasi SMAN di Palangka Raya. Penelitian ini menggunakan metode kuantitatif. Sampel penelitian ini adalah 389 orang guru yang bertugas di SMAN di Kota Palangka Raya. Teknik pengumpulan data dengan teknik survey melalui penyebaran angket. Teknis analisis data yang digunakan adalah secara deskriptif dan analisis inferensial (uji hipotesis). Analisis inferensial (uji hipotesis digunakan untuk menguji hipotesis penelitian melalui jalur analisis alur (Path Analysis). Berdasarkan hasil analisis data penelitian dapat disimpulkan disimpulkan bahwa $P O S$ berpengaruh langsung positif terhadap komitmen organisasi, sehingga dapat diartikan ketepatan POS yang dirasakan guru berdampak pada peningkatan komitmen organisasi guru SMA Negeri se Kota Palangka Raya.
\end{abstract}

Kata Kunci: Perceived Organizational Support, Komitmen Organisasi, SMAN Palangka Raya.

\begin{abstract}
Abstract: The purpose of this study is to comprehensively understand the effect of Perceived Organizational Support (POS) on Organizational Commitments of SMAN in Palangka Raya. This research uses quantitative methods. The sample of this study was 389 teachers who served at SMAN in Palangka Raya City. Data collection techniques with survey techniques through questionnaires. The data analysis technique used is descriptive and inferential analysis (hypothesis testing). Inferential analysis (hypothesis testing is used to test research hypotheses through path analysis). Based on the results of the analysis of research data it can be concluded that the POS has a direct positive effect on organizational commitment, so it can be interpreted POS accuracy perceived by teachers has an impact on increasing the commitment of teacher organizations Public High Schools in the City of Palangka Raya.
\end{abstract}

Keywords: Perceived Organizational Support, Organizational Commitment, SMAN Palangka Raya.

\section{PENDAHULUAN}

Kota Palangka Raya dalam rancangannya diarahkan kepada Kota Jasa Pendidikan yang dikarenakan dilihat dari sisi dan struktur ekonomi Kota Palangka Raya merupakan penyumbang terbesar terhadap PDRB pada sektor jasa-jasa. Dari hal ini terindikasikan bahwa sektor jasajasa termasuk Sub sektor jasa pendidikan memiliki potensi besar dalam peningkatan PDRB dan pertumbuhan ekonomi daerah Kota Palangka Raya. Hal tersebut juga ditunjang dengan keseriusan pemerintah pada sektor pendidikan terutama bagi para guru dan dosen, di mana hal tersebut sebagai komitmen pemerintah dalam mengupayakan hal-hal yang berkaitan dengan pembangunan pendidikan nasional sebagai bagian dari komitmen pemerintah dalam upaya meningkatkan kesejahtraan guru, dosen dan tenaga kependidikan, sebagaimana diamanatkan dalam Undang-Undang Nomor 14 Tahun 2005 tentang Guru dan Dosen pada pasal 53, serta Peraturan Pemerintah No. 41/2009 tentang Tunjangan Profesi Guru dan Dosen, Tunjangan Khusus Guru dan Dosen, serta tunjangan kehormatan Profesor.

Sejalan dengan itu penyelenggaraan pendidikan formal baik setingkat provinsi maupun kota dapat menyelenggarakan pendidikan yang berkualitas dan menyediakan para 
pendidik yang profesional juga, terlebih lagi bagi para pendidik yaitu sebagai guru, di mana tenaga pendidikan merupakan hal yang terpenting. Dewasa ini problema internal guru sebagai tenaga kependidikan yang profesional adalah menjadi ujung tombak keberhasilan pembangunan di bidang pendidikan. Di mana yang sering disoroti bahwa sekarang ini telah terjadi kecendungan menurunnya kualitas guru. Hal ini perlu disikapi dengan arif dan bijaksana, dalam menanggapi hal-hal positif melalui upaya dalam mengubah kemampuan masing-masing guru, salah satunya dengan membangun sebuah komitmen yang tinggi dan fungsi daripada organisasi terhadap setiap guru-guru.

Begitu juga berpihak kepada tujuan-tujuan organisasi tidak akan bermakna tanpa adanya keterlibatan individu dalam mencapai tujuan-tujuan organisasi. Slocum dan Hellriegel (2011) mengemukakan komitmen organisasi adalah kuatnya keterlibatan pegawai pada suatu organisasi dan berpihak kepada organisasi tersebut. komitmen organisasi yang kuat ditandai oleh: sebuah dukungan dan penerimaan tujuan organisasi dan nilai-nilai; kesediaan untuk mengerahkan usaha sungguh-sungguh atas nama organisasi; dan keinginan untuk mempertahankan keanggotaan dan tetap berada di dalam organisasi). Sehubungan dengan hal di atas, Newstrom (2012) juga menjelaskan: Commitment is akin to being strongly connected and engaged with the organization on an emotional level. It often reflects the employee's belief in the mission and goals of the firm, willingness to expend effort in their accomplishment, and intentions to continue working there.

Komitmen organisasi merupakan kekuatan keterlibatan karyawan dalam suatu organisasi (Colquit, Lepine, dan Wesson, 2009:67). Karyawan yang tinggal dengan organisasi untuk jangka waktu yang panjang cenderung jauh lebih berkomitmen kepada orgnisasi dari pada mereka yang bekerja dalam waktu yang lebih singkat. Pendapat yang senada dikemukakan Newstrom (2007:207) yang menyatakan bahwa komitmen organisasi merupakan "the degree to which an employee identifies with the organizational and wants to continue actively participating in it". Komitmen organisasi menggambarkan sejauh mana karyawan mengenali organisasi yang mempekerjakannya, yang merupakan keinginan karyawan untuk berupaya besar dengan niatnya untuk tinggal dengan organisasi ataupun keterikatan dengan organisasi untuk waktu yang lama disertai partisipasi aktif.

Komitmen organisasi merupakan hal yang amat penting dalam upaya meningkatkan kinerja sekolah, baik secara personal maupun organisasional. Komitmen pasti akan mendorong rasa percaya diri dan semangat kerja mereka. Komitmen akan memperlancar pergerakan sekolah mencapai goal setting perubahan. Hal ini ditandai dengan terciptanya peningkatan, baik bersifat fisik maupun psikologis, sehingga segala sesuatunya menjadi menyenangkan bagi seluruh warga sekolah. Karena daripada itu organisasi merupakan wadah untuk memenuhi kebutuhan manusia, sebaliknya kebutuhan manusia merupakan obyek kegiatan organisasi. Organisasi terbesar yang dibentuk manusia untuk memenuhi kebutuhan selain organisasi pemerintahan, juga ada organisasi swasta yang berfungsi sebagai penyedia layanan kepada masyarakat dalam memenuhi kebutuhan masing-masing.

Rendahnya komitmen organisasi, diperkuat dengan adanya pernyatan dari Panyaruwe, beliau mengatakan bahwa yang mudah bagi kepala sekolah dan yayasan adalah melengkapi bangunan fisik, fasilitas dan infrastruktur lainnya. Mengapa mudah, sebab kuncinya hanya pada satu kata, yaitu dana. Sedangkan guru adalah intisari sebagai seseorang pendidik yang profesional untuk menyampaikan pengetahuan dan pembelajaran justru menjadi problema 
yang dikarenakan rendahnya komitmen guru dan kualitas guru. Artinya pentingnya guru sebagai sumber daya manusia yang mempunyai komitmen tinggi terhadap pekerjaannya.

$P O S$ menjadi sangat penting jika mengikuti perkembangan dunia kerja, saat ini tenaga kerja dihadapkan dengan berbagai pilihan pekerjaan dengan situasi dan lingkungan kerja yang beragam. Setiap situasi dan lingkungan kerja tersebut tentunya memiliki tantangan dan tingkat kesukaran masing-masing. Tenaga kerja saat ini tidak hanya dituntut pintar dalam menyelesaikan tugas tapi juga harus mampu bertahan dan tetap loyal pada organisasinya meskipun konsekuensinya mereka harus berhadapan dengan sebuah lingkungan kerja yang mudah memicu stress dan tantangan karena itulah dukungan dari organisasi sangat mereka butuhkan untuk menjaga kualitas kerja dan komitmen mereka terhadap organisasinya.

$\begin{array}{crr}\text { POS } & \text { berpengaruh } & \text { terhadap } \\ \text { komitmen } & \text { Organisasi. } & \text { Guru }\end{array}$
mengharapkan adanya dari usaha mereka dalam menyelesaikan tugas dapat menghasilkan sesuatu untuk penyediaan manfaat nyata, seperti halnya medis, tunjangan, kenaikan Gaji/Honor serta adanya perawatan baik secara sarana prasarana hingga kedudukannya serta rasa dihormati dan dimiliki oleh organisasi tersebut. Oleh karena itu, dukungan organisasi yang dirasakan memperkuat upaya guru untuk secara efektif dapat memberikan hasil yang baik bagi organisasi.

Rhodes dan Eisenberger (1986) menjelaskan POS merupakan keyakinan karyawan mengenai sejauh mana organisasi peduli menghargai kontribusi serta memperhatikan kesejahtraannya. Hal ini juga berkaitan pada teori pertukaran sosial exchange teory di mana hubungan antara pegawai dan organisasi adalah merupakan suatu hubungan pertukaran, misalnya suatu pegawai mau bekerja disuatu organisasi karena pegawai tersebut hendak mempertukarkan usaha dan loyalitasnya dengan imbalan materi sosio-emosional tertentu. Rhodes dan Eisenberger (2012) menyatakan sejauh mana yang dirasakan sebagai dukungan juga berkaitan dengan kebutuhan untuk pujian dan pesetujuan, karyawan akan menggambungkan organisasi keanggotaannya dalam identifikasi diri dan dengan demikian dapat mengembangkan ikatan emosional positif kepada organisasi.

Berkaitan dengan POS yang telah dijelaskan di atas, keterlibatan kerja guru merupakan faktor penting di mana keterlibatan kerja bagi guru adalah hal-hal yang berkaitan dengan program-progam kerja sekolah. Guru sebagai pelaksana kegiatan sekolah, maka guru tentunya yang banyak mengerti tentang kebutuhan sekolah dan siswanya. Pengelolaan belajar, kelas kesiswaan, penilaian dan hasil belajar siswa dan lain sebagainya yang seluruhnya berada di manajemen guru. Oleh karena itu, peranan guru dalam pengelolaan sekolah baik itu pembiayaan, penyelenggaraaan, pengadaan dan pengembangan sekolah tidak terlepas dari peran serta, dan tangungjawab dan keterlibatan guru didalamnya.

Walaupun berbagai upaya yang telah dilakukan untuk mencapai proses pembelajaran yang maksimal, namun pada kenyataannya tidak semua sekolah Negeri yang memiliki kualitas yang dapat dikatakan bersaing dengan sekolahsekolah lainnya. Hanya sekolah-sekolah Negeri tertentu yang menjadi sekolah unggulan dikalangan masyarakat, sedangkan sekolah yang kurang memiliki kualitas tinggi serta rendahnya para pendidik yang profesional mengakibatkan kurangnya komitmen organisasi dalam ruang lingkup pekerjaan.

Isu -isu yang terkait terhadap rendahnya komitmen organisasi di Kota Palangka Raya dapat dilihat melalui dua sisi yaitu: (1) Loyalitas, dalam hal kesedian guru masih kurang untuk mempertahankan diri bekerja dalam 
organisasi secara professional, dan (2) Keterlibatan dalam melakukan hal aktivitas-aktivitas yang dilakukan organisasi masih kurang. Pernyataan tersebut bertolak belakang dengan penyataan Tanthowi bahwa seorang guru dituntut memiliki kompetensi sebagai tenaga didik dan kualifikasi akademik yang memadai, guru juga harus sehat jasamani dan rohani serta mampu mewujudkan tugas pendidikan nasional. Disamping memegang 10 komitmen PNS, yait: komitmen pada pelayanan, kualitas pelayanan, kualitas pekerjaan, mampu menyelesaikan persoalan, komitmen untuk terus bekerja, cepat merubah kebiasaan yang tidak baik, komitmen untuk saling menghargai, saling bekerja sama, disiplin, bekerja jujur dan komitmen untuk bekerja dengan ikhlas.

Komitmen organisasi yang tinggi berarti terdapat keberpihakan kepada organisasi yang tinggi pula. Komitmen sebagai prediktor kinerja seseorang merupakan prediktor yang lebih baik dan bersifat global. Bertahan dalam organisasi sebagai suatu keseluruhan daripada kepuasan kerja semata. Seseorang dapat tidak puas dengan pekerjaan tertentu dan menganggap sebagai kondisi sementara, tapi tidak puas terhadap organisasi adalah sebagai suatu keseluruhan, dan ketidakpuasan tersebut bila menjalan ke organisasi dapat mendorong seseorang untuk mempertimbangkan diri minta pemberhentian.

Kondisi daripada pernyataan di atas juga tidak jauh berbeda dengan halhal yang berkaitan dengan komitmen organisasi guru yang terjadi pada sektor pendidikan di Kota Palangka Raya, berdasarkan data hasil wawancara dengan Koordinator Pengawas menunjukkan $\mathrm{m}$ apa yang terjadi pada guru SMA Negeri di kota Palangka Raya secara umum, baik yang dilaksanakan oleh pihak sekolah maupun instansi pemerintah terkait sehingga menyebabkan rendahnya komitmen organisasi, diantaranya adalah: (1) Palangka Raya adalah kota yang sedang berkembang dan membutuhkan guru-guru yang mau berkomitmen untuk meningkatkan mutu pendidikan dalam rangka mendukung pendidikan di Kota Palangka Raya, (2) kurangnya sikap responsif dan inovatif terhadap perkembangan zaman sehingga mengurangi keinginan untuk menjadi lebih baik, baik itu sebagai guru profesional maupun sebagai pendidik yang bertanggung jawab, (3) masih rendahnya kepedulian organisasi terhadap para guru, (4) kurangnya kesadaran etika profesi yang terjadi akhir-akhir ini menunjukkan merosotnya nilai-nilai kerja, dan (5) masih rendahnya keinginan pada keterlibatan pekerjaan dalam sebuah kegiatan organisasi maupun dalam hal lain yang berkaitan dengan kemajuan organisasi, sehingga tidak hanya terfokus pada satu unit pekerjaan maupun hanya mengurus kelas.

Berdasarkan fakta yang mendasari latar belakang masalah di atas, dapat disimpulkan bahwa tinggi rendahnya kualitas pendidikan sangat dipengaruhi bagaimana peran guru dalam melaksanakan proses sebagai capaian yang menjadi dasar bagi guru dalam bekerja dan loyalitas serta mempunyai komitmen organisasi yang tinggi pada sekolah, oleh kerena itu diperlukan berbagai usaha untuk meningkatkan profesionalisme guru. Dalam hal ini, banyak faktor yang mempengaruhi komitmen organisasi diantaranya adalah Perceived Organizational Support (POS). Pemberian POS yang baik akan meningkatkan komitmen organisas. Soleh (2018) dalam penelitiannya menyimpulkan terdapat hubungan positif antara variabel POS dan komitmen organisasi. POS berpengaruh signifikan terhadap kinerja karyawan dengen komitmen organisasi (Giraldi, 2017).

\section{METODE}

Penelitian ini secara umum bertujuan untuk mengetahui pengaruh dari Perceived Organizational Support (POS) 
terjadap Komitmen Organisasi. Populasi dalam penelitian ini adalah para guru PNS yang bertugas pada SMA Negeri di Kota Palangka Raya yang tersebar di 4 kecamatan, yaitu kecamatan Pahandut, Jekan Raya Bukit Batu dan Rakumpit. Total populasi yang menjadi sampel dalam penelitian ini sebanyak 389 orang. Teknis analisis data yang digunakan adalah secara deskriptif dan analisis inferensial (uji hipotesis). Penggunaan analisis data deskriptif digunakan untuk mengambarkan keadaan data masingmasing variabel, yaitu skor terendah, skro tertinggi, skor rata-rata median, modus, standar deviasi, varians, distribusi frekuensi, dan histrogram. Sedangkan analisis inferensial (uji hipotesis digunakan untuk menguji hipotesis penelitian melalui jalur analisis alur (Path Analysis).

\section{HASIL DAN PEMBAHASAN \\ Hasil}

1. Komitmen Organisasi

Berdasarkan data yang diperoleh di lapangan yang kemudian diolah secara statistik ke dalam daftar distribusi frekuensi, banyaknya kelas di hitung menurut aturan Sturges, diperbolehkan delapan kelas dengan nilai skor maksimum 160 dan skor minimum 80 , sehingga rentang skor sebesar 80. Dari hasil perhitungan statistik deskriptif diperoleh bahwa instrumen komitmen organisasi mempunyai nilai rata-rata (mean) sebesar 117.98 dengan nilai standar deviasi 17,72 dimana nilai variannya sebesar 313.99 nilai median 117 dan nilai modus sebesar 114. Pengelompokan data dapat dilihat pada Tabel 1. Distribusi frekuensi Skor Variabel Komitmen Organisasi.

\section{Perceived Organizational Support (PSO)}

Berdasarkan data yang diperoleh dari lapangan, data variabel $P O S$ mempunyai rentang skor antara 152 sampai 81 sehingga rentang skor sebesar 71. Hasil perhitungan data di peroleh ratarata sebesar 117,72 simpangan baku sebesar 15,14 varians sebesar 229,37 median sebesar 118 dan modus sebesar 117. Data POS disajikan dalam bentuk distribusi frekuensi dalam Tabel 2.

Tabel 1. Distribusi Frekuensi Skor Variabel Komitmen Organisasi

\begin{tabular}{ccccccc}
\hline \multirow{2}{*}{ No } & \multirow{2}{*}{ Kelas Interval } & \multicolumn{2}{c}{ Batas } & \multicolumn{3}{c}{ Frekuensi } \\
\cline { 2 - 7 } & Bawah & Atas & Absolut & Komulatif & Relatif \\
\hline 1 & $80-88$ & 79,5 & 88,5 & 8 & 8 & $4,1 \%$ \\
\hline 2 & $89-97$ & 88,5 & 97,5 & 18 & 26 & $9,1 \%$ \\
\hline 3 & $98-106$ & 97,5 & 106,5 & 26 & 52 & $13,2 \%$ \\
\hline 4 & $107-115$ & 106,5 & 115,5 & 37 & 89 & $18,8 \%$ \\
\hline 5 & $116-124$ & 115,5 & 124,5 & 44 & 133 & $13,7 \%$ \\
\hline 6 & $125-133$ & 124,5 & 133,5 & 27 & 160 & $8,1 \%$ \\
\hline 7 & $134-142$ & 133,5 & 142,5 & 16 & 176 & $6,1 \%$ \\
\hline 8 & $143-151$ & 142,5 & 151,5 & 12 & 188 & $4,6 \%$ \\
\hline 9 & $152-160$ & 151,5 & 160,5 & 9 & 197 & $\mathbf{1 0 0 \%}$ \\
\hline
\end{tabular}

Tabel 2. Distribusi Frekuensi Skor Variabel POS

\begin{tabular}{ccccccc}
\hline \multirow{2}{*}{ No } & \multirow{2}{*}{ Kelas Interval } & \multicolumn{3}{c}{ Batas } & \multicolumn{3}{c}{ Frekuensi } \\
\cline { 2 - 7 } & & Bawah & Atas & Absolut & Komulatif & Relatif \\
\hline 1 & $81-88$ & 80,5 & 88,5 & 6 & 6 & $3,0 \%$ \\
\hline 2 & $89-98$ & 88,5 & 98,5 & 12 & 18 & $6,1 \%$ \\
\hline 3 & $97-104$ & 96,5 & 104,5 & 20 & 38 & $10,2 \%$ \\
\hline 4 & $105-112$ & 104,5 & 112,5 & 34 & 72 & $17,3 \%$ \\
\hline 5 & $113-120$ & 112,5 & 120,5 & 41 & 113 & $20,8 \%$ \\
\hline 6 & $121-128$ & 120,5 & 128,5 & 34 & 147 & $17,3 \%$ \\
\hline 7 & $129-136$ & 128,5 & 136,5 & 27 & 174 & $13,7 \%$ \\
\hline 8 & $137-144$ & 136,5 & 144,5 & 16 & 190 & $8,1 \%$ \\
\hline 9 & $145-152$ & 144,5 & 152,5 & 7 & 197 & $3,6 \%$ \\
\hline \multicolumn{7}{r}{ Jumlah } \\
\hline
\end{tabular}


Pengujian Persyaratan Analisis

Penggunaan statistik parametris pada penelitian ini bekerja dengan asumsi bahwa data setiap variabel yang dianalisis membentuk distribusi normal. Proses pengujian persyaratan analisis pada penelitian ini merupakan syarat yang harus dipenuhi agar penggunaan teknis regresi yang termasuk pada kelompok statistik parametris dapat diterapkan untuk keperluan pengujian hipotesis. Syarat analisis jalur (path analysis) adalah estimasi antara variabel eksogen terhadap variabel endogen bersifat linier, dengan demikian persyaratan yang berlaku pada analisis regresi dengan sendirinya juga berlaku pada persyaratan analisis jalur. Persyaratan yang harus dipenuhi dalam analisis jalur adalah bahwa sampel penelitian berasal dari populasi yang berdistribusi normal dan pengaruh antara variabel-variabel dalam model haruslah signifikan dan linier. Berkaitan dengan hal tersebut, sebelum dilakukan pengujian model lebih dahulu dilakukan pengujian terhadap kedua persyaratan yang berlaku dalam analisis jalur tersebut. Pengujian analisis yang dilakukan adalah: (1) Uji
Normalitas, dan (2) Uji Signifikansi dan Linieritas Koefisien Regresi.

Pengujian Hipotesis

Hipotesis penelitian dapat terjawab setelah melakukan analisis model. Analisis model digunakan sebagai dasar dalam menjawab hipotesis dan menarik kesimpulan pada penelitian ini. Penjelasan terhadap jawaban hipotesis tersebut dapat diuraikan sebagai berikut:

POS berpengaruh langsung positif terhadap komitmen organisasi

$\mathrm{H}_{0}: \beta_{31} \leq 0$
$\mathrm{H}_{1}: \beta_{31}>0$
$\mathrm{H}_{0}$ ditolak, jika $\mathrm{t}_{\text {hitung }}>\mathrm{t}_{\text {tabel }}$

Berdasarkan dari data hasil perhitungan analisis jalur, pengaruh langsung $P O S$ terhadap komitmen organisasi memiliki nilai koefisien jalur sebesar 0,496. Setelah itu dilakukan uji-t terhadap nilai koefisien jalur untuk mengetahui signifikansi koefisiensi jalur tersebut sebagaimana tercantum pada Tabel 3.

Tabel 3. Hasil Uji Signifikansi Koefisien Jalur POS dengan Komitmen Organisasi

\begin{tabular}{cccc}
\hline Pengaruh Langsung & Koefisien Jalur & thitung $^{n}$ & $\mathbf{t}_{\text {tabel }}$ \\
\hline X terhadap Y & 0,492 & $13,457^{* *}$ & $\boldsymbol{\alpha}=\mathbf{0 , 0 1}$ \\
\hline ** Sangat Signifikan $(13,457 \geq 2,36$ pada $\alpha=0,01)$ &
\end{tabular}

Berdasarkan tabel 3. di atas didapatkan nilai koefisien $t_{\text {hitung }}$ sebesar 13,457 . Nilai koefisien tabel untuk $\alpha=0,01$ sebesar 2,36. Oleh karena nilai koefisien thitung lebih besar dari nilai $t_{\text {tabel }}$ yaitu 13,457>2,36 maka dengan demikian $\mathrm{H}_{0}$ ditolak dan $\mathrm{H}_{\mathrm{i}}$ diterima, dalam arti kata bahwa $P O S$ berpengaruh secara langsung terhadap komitmen organisasi dapat diterima.

Hasil analisis hipotesis tersebut memberikan temuan bahwa POS berpengaruh langsung positif terhadap komitmen organisasi. Dengan demikian dapat disimpulkan bahwa komitmen organisasi dipengaruhi secara langsung positif oleh POS. Perluasan POS mengakibatkan peningkatan komitmen organisasi.

\section{Pembahasan}

Berdasarkan hasil pengujian hipotesis, dapat disimpulkan bahwa terdapat pengaruh langsung positif $P O S$ terhadap komitmen organisasi dengan nilai koefisien korelasi sebesar 0,671 dan nilai koefisien jalur sebesar 0,496 . Hal tersebut memberikan makna bahwa $P O S$ berpengaruh langsung terhadap komitmen organisasi. Hasil temuan penelitian ini 
senada dengan yang dikemukakan oleh Eisenberger dan Huntington (1986) bahwa kami melaporkan bukti luas dan konsistensi keyakinan guru tentang komitmen organisasi yang dirasakan dan pengaruh dukungan organisasi dirasakan tersebut dan ideologi pertukaran guru terhadap absensi.

Perihal senada juga dikemukakan LaMastro (1999) bahwa persepsi guru terhadap dukungan organisasi berpengaruh pada komitmen organisasi dimana secara keseluruhan, tampak bahwa guru dengan tingkat POS yang lebih tinggi cenderung lebih berkomitmen dan mungkin lebih bersedia untuk terlibat melakukan peran-peran tambahan atau menunjukkan perilaku yang lebih dibandingkan guru yang merasa bahwa organisasi mereka sangat tidak menghargai mereka. Individu yang merasa mendapatkan dukungan organisasi yang sangat kuat cenderung setia terhadap organisasi dan tidak berniat untuk mencari pekerjaan lain di tempat lain. Ucar dan Otken (2010) dalam penelitiannya menyimpulkan terdapat pengaruh antara POS dengan komitmen organisasional, POS telah dihipotesiskan untuk mempengaruhi reaksi umum guru untuk pekerjaan mereka diantaranya termasuk kepuasan kerja, keterlibatan kerja, komitmen organisasi, dan niat untuk meninggalkan pekerjaan.

Berdasarkan pendapat tersebut menunjukkan bahwa berdasarkan hasil studi cenderung dan dapat dikatakan untuk membuktikan bahwa POS berdampak pada komitmen organisasi. Guru yang memiliki kepercayaan positif terhadap organisasinya cenderung lebih loyal dan memiliki rasa keterikatan serta komitmen terhadap organisasinya. Berdasarkan penjelasan di atas jelaslah bahwa $P O S$ berpengaruh langsung positif terhadap komitmen organisasi.

\section{SIMPULAN}

Berdasarkan hasil penelitian dan pembahasan yang telah diuraikan sebelumnya, dapat disimpulkan bahwa $P O S$ berpengaruh langsung positif terhadap komitmen organisasi. Artinya ketepatan POS yang dirasakan guru berdampak pada peningkatan komitmen organisasi guru SMA Negeri se Kota Palangka Raya.

\section{UCAPAN TERIMA KASIH}

Ucapan terima kasih penulis sampaikan kepada para pihak Dinas Pendidikan Provinsi Kalimantan Tengah telah memberikan kemudahan akses untuk melaksanakan penelitian pada SMA Negeri di kota Palangka Raya, serta Redaksi Equity in Education Journal (EEJ) yang telah memberikan kesempatan artikel saya dapat dimuat dalam jurnal ini.

\section{DAFTAR PUSTAKA}

Colquitt, J., Lepine, J., \& Wesson, M. (2009). Organizational Behavior: Improving Performance and Commitment in the Worplace. New York: McGraw-Hill Companies Inc.

Eisenberger, R., \& Huntington, R. (1986). Perceived Organizational Support. Journal of Applied Psychology, (71)3.

Giraldi, N. V. N. (2017). Pengaruh Perceived Organizational Support terhadap Kinerja Karyawan dengan Komitmen Organisasional sebagai Variabel Intervening pada Karyawan Bidang Transmisi Distribusi PDAM Delta Tirta Sidoarjo. Skripsi, tidak dipublikasikan, Fakultas Ekonomi dan Bisnis Universitas Airlangga Surabaya.

LaMastro. V. (1999). Commitmen and Perceived Organizational Support". National Forum of Applied Educational Research Journal, (12)2.

Newstrom, J. W., \& Davis, K. (2012). Organizational Behavior (New York: International Edition, Inc. 
Peraturan Pemerintah Nomor 41 Tahun 2009 tentang Tunjangan Profesi Guru dan Dosen, Tunjangan Khusus Guru dan Dosen, serta Tunjangan Kehormatan Profesor.

Robbins, S. P., \& Coulter, M. (2012). Management. United States: Pearson Education, Inc.

Slocum. J. W., \& Hellriegel, D. (2011). Principles of Organizational Behavior. South-Western: Cengage Learning.

Soleh, A. R. (2018). Hubungan Persepsi Dukungan Perceived Organizational Support dengan Komitmen Organisasi pada
Pegawai BLU UIN Sunan Ampel Surabaya. Skripsi, tidak dipublikasikan, Fakultas Psikologi dan Kesehatan Universitas Islam Negeri Sunan Ampel Surabaya.

Uçar, D., \& Ötken, A. B. (2010). Perceived Organizational Support and oOganizational Commitment: The Mediating Role of Organization Based Self-Esteem. Dokuz Eylül Üniversitesi Íktisadi ve İdari Bilimler Fakültesi Dergisi, (5)85-105. www.dergi.iibf.deu.edu.tr.

Undang-Undang Nomor 14 Tahun 2005 tentang Guru dan Dosen. 